\title{
AN ASSESSMENT OF PARTICIPATORY APPROACH ON WATER SUPPLY (A CASE STUDY OF JIMETA - YOLA NORTH LOCAL GOVERNMENT AREA)
}

\author{
AJAYI A. P \& OTINYA. O. S
}

Department of Urban and Regional Planning, Modibbo Adama University Yola, Nigeria

\begin{abstract}
This paper assesses the level of participatory planning approach on water supply in Yola ררי North Local Government Area, and to push further in identifying existing stakeholders, the roles they play, and measures put in place by the state water agency to adopt healthy and sustainable participatory planning practices in water supply schemes. Participatory planning approach has been an age long reoccurring activity either in physical planning, human, economic or environmental development activities in developed nations mostly in Europe and the Americas, and in recent times has gradually become a growing trend, especially in water supply development activities in developing countries in parts of Asia and Africa, but the major challenges have always been how to categorize the level of involvement of all stakeholders especially the urban poor.

Results and major findings revealed that there is a wide gap existing between areas of relatively adequate water supply and those with inadequate, the widespread of failed water supply schemes has been as a result of low-level to non-existence of participatory planning activities on water supply schemes, continuous adoption of poor and ineffective policy implementation process for water supply projects, professional lack of zeal to fully understand the plight of the urban poor and how to act as catalyst to participatory planning process, and end-users understanding of their rights to be involved and their collective responsibilities for sustainable water supply schemes in the study areas. It is recommended that there should be a re-evaluation of the planning and implementation process for water supply schemes, a streamlined fiscal policy for water supply schemes, adopt a participatory approach to strengthen the synergy between all stakeholders, and planning process of any future water supply schemes should be designed on the bases of the framework suggested.
\end{abstract}

KEYWORDS: Water Supply, Participatory Planning, Stakeholders, Water Agencies \& End $\neg$-Users

Received: Jul 01, 2021; Accepted: Jul 21, 2021; Published: Aug 12, 2021; Paper Id.: IJEEFUSDEC20219

\section{INTRODUCTION}

There is a growing policy emphasis on the involvement of stakeholders and the public in water resource planning and decision making especially in the aspect of water supply (Global Water Partnership, 2000). In Europe, participation in water resource planning gained a new institutional statue with the Water Framework Directive (WFD). This calls for the "active involvement" of all interested parties in the implementation process and particularly in the production, revision, and updating of River Basin Management Plans (Article 14; Council of the European Communities, 2000). Planning methods that combine participatory approach with decision making functions are therefore increasingly in demand (Commission of the European Communities, 2002).

Participatory approaches have proven to be effective in natural resource development planning (Chambers, 1994a; Shah, 1993; Devavaram, et al. 1991). Villages or small communities are often depicted as examples of 
participatory planning, thus, the scope of the planning unit is always small. There is always the problem of "scale up" in participatory approach that involves single communities with close association to groups of more complex planning entities, as in the case of urban areas (Chambers, 1994b; Webber and Ison, 1995).

Participatory approaches did not appear spontaneously, nor do they exist in a vacuum. They emerged from a long history of trial and error in the rural water supply sector, and are linked to and affected by developments in many other sectors, particularly those related to more general rural development, but also natural resource management, and specifically water resource management (Schouten and Moriarty, 2003:)

Participatory planning approach is suggested by the World Bank as one of the alternative ways of managing water resources in urban areas because active involvement of the end-users would help to make water supply schemes sustainable, creates a sense of ownership, legitimacy and protection of infrastructure (TASAF operational manual, 2008).

From the foregoing, this paper aims at assessing the level of participatory planning approaches in water supply schemes within Jimeta Metropolis with the specific objectives as follows:

- To assess stakeholder roles and participatory level in water supply projects in their respective communities and Neighbourhoods

- To examine the participatory planning measures put in place by Adamawa State water Board Authority to address dilapidation in water supply facilities.

- To present workable planning recommendations to achieve effective participatory planning in water supply schemes in Jimeta-Yola-North Local Government Area.

\section{MATERIALS AND METHODS}

In the conduct of this research, various methods were employed for the procurement of the relevant information and data for the research work (Bazza et- al, 2009) Data required to satisfy the objectives of this study include existing water facilities in Yola North L.G.A, factors determining the location and selection of water facilities and factors affecting demand and supply, as well as the pattern of supply.

The primary data will be obtained from field survey of the existing facilities in the study area, personal interviews with the people living in that particular environment and those in charge of running and managing the existing facilities as well as the government agency that is saddled with the responsibility of providing water facilities. It will also include administration of questionnaires and personal observation.

Secondary data will be obtained from publications such as journals, magazines, national dailies and some relevant unpublished materials.

The urban landscape in developing nations is fast changing both in structures and in forms, and the demand for water supply has become a widely debated issue owing to the inadequate urban water delivery system that has tremendously been on the decrease due to inadequate participatory approach in water supply networks, growth of informal settlements leading to spatial disparities in terms of living condition and water infrastructure development, as well as poor urban water and structural policy framework in Nigerian development policies. 


\section{RESULTS AND DISCUSSIONS}

Despite the effort of the state government in the construction of several water supply projects within Jimeta Metropolis from 2004 to 2018, these water supply projects failed to achieve their desired goal. Preliminary investigation revealed a hand full of factors that led to these recorded failures. Factor such as the adoption of a Top-down approach in the form of Supply Driven Implementation Approach (SDIA), to Demand Responsive Approach making Adamawa State government, and her respective relevant agencies to be the sole initiator, planner and provider of water supply service interventions in the study area.

Stakeholders involvement in development activities in the Yola-North is yet to be a regular part of the Government Structures, it is still at its pre-institutionalized state amidst important leverage points and using collective effort to form partnership between the public and water agency. While Bates claims that participatory planning is a dynamic process, he also mentioned that the pattern of change should be in accordance with the needs and aspirations of all stakeholders (Bates, 2008)

In effect, participatory planning approach may change the Governance function on community/neighbourhood water supply in Yola- North Local Government Area. The introduction of collective effort as a tool in which end-users can accomplish their goals of fostering connection and determining who they really are as a community will serve as a catalyst in the dynamic system leading to better participation.

\section{SUMMARY OF FINDINGS}

Findings show that residents of Yola North LGA have become so accustomed to being responsible for the provision of their daily water supply needs and that they no longer see the relevance of the government in providing water supply to them. It was also observed that inadequate urban water supply poses threats to not only the wellbeing of the people of the study area, but also to the wellbeing of plants and animals, socio-economic activities, and urban vegetative cover. In essence, they have lost all confidence in governance and in her responsibility to provide adequate water supply.

It was discovered that in the past Eighteen years (1999 to 2018), a total of One Billion, Five Hundred and Eighty Nine Million, Five Hundred and Thirty Thousand, Seven Hundred and Seventy Two Naira $(N 1,589,530,772)$ was spent on both direct and indirect water supply related projects, none of these water supply project that took place within this timeframe in the study area were MDG's related water supply projects nor had any funding from World Bank MDGs counterpart funds, and supply driven and demand responsive approach was adopted in the course of all these water supply projects carried out within this period with little to no consideration given to other stakeholders most especially the endusers that have very high stakes in all these water supply projects.

\section{RECOMMENDATION AND CONCLUSION}

It is recommended that

- Participatory approach should be fully adopted in the planning process for all water supply schemes.

- Water resources professionals from the Adamawa State Water Board Authority, planners, influential corporate and public officials should serve in a capacity that will create a push (catalyst) to the participatory planning process for water supply scheme. 
- There should be a synergic relationship should be established between the state water supply agency and planning authority. Planning authorities at all levels of government should be actively engaging in all water supply schemes in other for there to be equity in the distribution of available resources for proper monitoring, supervision and implementation of water supply projects in accordance with the physical planning characteristics of the study area.

- Professionals should not only view stakeholders in the context of those having vested interest but rather, efforts should be made to have proper stakeholders mapping, there is a need to identify and clearly outline their interests and needs, their functions and level of participation should be clearly stated and also, there should be room for dialogue among stakeholders as well as capacity development especially for those community stakeholders that have to participate but lacks the political will.

- Plan negotiation and assessment is one vital aspect of development projects. Project facilitators should create an enabling environment for stakeholders input in identifying and assessing existing problems, state the level of incorporation of measures to be taken, manage conflict of interest that may arise, build consensus in goals prioritization and plan draft.

- Participatory approach is a system that is very much dependent on the collective efforts, ideas and collaborations of individuals and groups. In other for this to go smoothly, professionals or experienced facilitators should act in the capacity of a catalyst fostering inclusivity in Governance and Resource collection for sustainable growth. They should also serve as leverage points, because their feedback into the general system will help to ignite a chain reaction of change.

- The state and the Local Government in particular with donor agencies as well as other corporate organizations, and community members should work in view of meeting sustainable development goals, ensuring the availability and sustainable management of water and sanitation for all through the provision of adequate water supply facilities in the study area.

- Water agency and donor agencies in the area should train selected neighborhood members to improve their skills and technical know-how to provide expertise for repairs and maintenance of water supply facilities in the study area.

In conclusion, an ideal planning process is participatory in nature and the inclusivity of key stakeholders in policy formulation for water supply development projects as well as the execution of these policies should not be confounded but rather adequately thought through to meet the needs and aspirations of each respective stakeholder especially the end-users that makes up the urban poor and underprivileged. This is because planning itself is often aimed at bridging gaps created by other decision makers and therefore it should not be all about the need to define planning and its relative systems, but to identify the real world challenges which our planning seeks to address.

The low level of participatory planning currently experienced in the study area is a result of Governments own inability to broaden the scope in adopting and implementing fiscal policies for water supply schemes, come up with workable guidelines to ensure adequate enlistment of private sector partnership and also providing adequate support and services to relevant agencies responsible for the provision of water supply in accordance to physical planning of the area. Bringing the Government and the people together through participatory approach, not only bringing about changes in the 
way the people view Governance and how development projects should be done but also improves the people's image as a community.

\section{REFERENCES}

1. Abdullahi B.M and Sahabo A.A (2015).

2. Water Supply and Distribution Problems in Development Countries: a Case Study of Jimeta-Yola, Nigeria. Department of Urban and Regional Planning, Modibbo Adama University of Technology Yola, Nigeria. International Journal of Scientific Engineering and Applied Science (IJSEAS)-volume-1, issue-4, June 2015 ISSN:23-95-3470 www.ijseas.com

3. Alvar, C., et-el (2012.) Integrated Urban water management- Lesson and recommendation from Regional Experience in Latin America, central Asia and Africa.

4. Asthana, D.K. and W. Asthana, (2001). Environmental: Problem and Solutions. Second Revised edition.

5. S. Chand and Company ltd, New Delhi. ISBN: 81-219-1654-2

6. Beierle, T.C.; Cayford, J Democracy in practice: Public Participation in Environmental Decision; Resource For The Future: Washington DC, USA, 2002.

7. Bates, N, (2000). The Community Planning Handbook: How People Can Shape Their Cities, Towns And Villages In Any Part Of The World, Earthscan, London.

8. Bates, n. (2000). The Community Planning Event Manual: How Can People Use

9. Collaborative Planning And Urban Design Events To Improve Your Environment, Earthscan, London.

10. Biswas, A.K. (2006). Water Management For Major Urban Centers. International Journal of Water

11. Resources Development, 22(2), 183-197. Doi: 10.1080/07900620600690789.

12. Chambers, R. 1994a. Participatory Rural Appraisal (PRA): Analysis of experience.

13. World Development, 22(9): 1253-1268

14. Chambers, r. 1994b. Participatory Rural Appraisal (PRA): Challenges, Potentials and Paradigms.

15. World Development, 22 (10): 1437-1454.

16. Chilvers, J. Deliberating Competence: Theoretical and Perspectives on Effective participatory Appraisal

17. Practice. Sci. Technol. Hum. Values 2008, 33, 155-185.

18. DFID, (2000). Strategies for achieving the International Development Targets: Addressing the Water Crisis- Healthier and Productive lives for the people. Encarta web Encyclopedia (2016). Vol 12

19. Erick, O.A (2015). The Role of Community Participation of In Water Production and Management:

20. Lesson from Sustainable Aid in Africa International Sponsored Water Schemes in Kisumu, Kenya. http:/scholarcommons.usf.edu/etd

21. Federal Ministry of Water Resources (2000). Water Supply and Sanitation Policy. Lagos, Nigeria.

22. Farley, J.; Costanza, R.; Envisioning Shared Goals For Humanity: A detailed, shared vision of a sustainable and desirable USA in 2100. Ecol. Econ. 20022, 43, 245-259

23. Fiorino, D., J Citizen Participation and Environmental Risk: A Survey Of Institution And Mechanism. Sci 
24. Technol. Hum. Values 1990, 15, 226-243.

25. Ghai, D., \& Vivian, J (2014). Grassroot Environmental Action: People Participation in Sustainable

26. Development. London: Routledge.

27. Global Water Partnership, 2000 Integrated Water Resource Management Background Paper 4, technical

28. Adviser committee (Global Water Partnership, Stockholm)

29. Ishaku, H.T., Ajayi A.P; Dama F.M; and Sahabo, A.A (2013).

30. Complimenting Water Supply Through Rainwater Harvesting In Some Selected Villages In Sahel Savannah Ecological Zone In Borno Sate North-Eastern Nigeria. Journal Of Water Resource Management. Springer Publisher Netherlands.

31. MacDonald AM, Davies J, Callow RC, and Chilton PJ (2005). Developing Ground Water:

32. A Guide for Rural Water Supply. ITDG Publishing, Rugby, UK.

33. Murray, M. Participatory Partial Planning: Learning From Rural Ireland. Ashgate Publishing Group, (2010). At http/site.ebrary.com/lib/alltiltles/docdetail.action?docID $=10421617$

34. Naiga,, R., Penker, M., \& Hogl, k. (2012). Evaluation of National Population Report on 2006

35. National Census.

36. Nicole, A. (2000). Adopting a Sustainable Livelihood to Water Projects: Implication for Policy and

37. Practices. OD1 Working paper 133, Overseas Development Institute, London UK

38. Olatunji, T., 2003. Towards making rural water supply work and sustainable. IN:

39. Harvey, $p$. (ed). Towards the millennium development goals-Action for water and environmental sanitation: Proceeding of the 19th WEDC International Conference, Abuja, Nigeria, 22 September 2003, pp. 134-135.

40. Reed, M.S, Stakeholder Participation for Environmental Management:

41. A literature review. Biological Conservation. 2008, 141, 2417-2431

42. [Saad-sulonen, J.(2012). The Role Of The Creation And Sharing Of Digital Media Content In

43. Participatory E-planning: International Journal Of E-Planning Research 1,1-22 (2012)]

44. Singh, N., Jacks G., Bhattacharya, P., 2005. Women And Community Water Supply Programmes:

45. An analysis from a socio-cultural perspective. Natural Resources Forum, 29: 213-223.

46. Stave, K.A.(2010).Participatory System Dynamics Modeling ForSustainable Environmental Management; Observation from four cases. Sustainability, 2(9), MDPI. http://dx.doi.org/10.3390/su2029762

47. Singh, N., Jacks, G., Bhattacharya, P., 2005. Women and community water supply programmes: an

48. Analysis from a socio-cultural Perspective. Natural Resources for, 29:213-223.

49. Krishnamoorthy, C., K. Soorianathasundaram, and S. Mekala. "Effect of fertigation on FUE, quality and economics of cultivation in turmeric (Curcuma longa L.) cv. BSR 2." International Journal of Agricultural Science and Research (IJASR) 5.1: 67-72.

50. Gangawane, Prashant, and Usha Sayed. "Innovative Use of outdated Doxycycline Hydrochloride to Dye wool." International Journal of Medicine and Pharmaceutical Sciences; 4 (2): 4346. 
51. Sharma, N. E. E. R. A. J., Y. P. Mathur, and A. S. Jethoo. "Effects of hydrological changes on the biodiversity at Keoladeo National Park and their impact on Ecotourism." International Journal of Civil, Structural, Environmental and Infrastructure Engineering Research and Development (IJCSEIERD) Vol, 5 (6), 110.

52. Wahid, Nusrat, Mahtab Hussain Siddiqui, and Asma Siddiqua. "The Quality of affordable rental accommodation: a case study on female migrant RMG workers in Gazipur, Dhaka, Bangladesh." International Journal of Humanities and Social Science, IASET 9.2: 89-100.

53. Ketaren, S., et al. "Environmental health aspect in health emergency management (a case study: Sinabung Vulcanous Eruption)." Int. J. Appl. Nat. Sci 5: 47-56.

54. Narmania, Davit. "Economic Policy Uncertainty and Risk Management in Regulated Sectors." International Journal of Business and General Management 7.4: 19-28.

55. Stephen N. Meno (2016), Thinking in Circles: a System Theory Approach to Public Participatory in planning. Thesis Submitted To The Graduate School Of The University Od Massachusetts Amherst In Partial Fulfillment Of The Requirements For The Degree Of Master Of Regional Planning. Department Of Landscape Architecture And Regional Planning 
